\section{Planting Date, Fertilizer Rate, and Harvest Timing Affect Yield of Jalapeño and Banana Peppers}

\author{
V.M. Russo \\ U.S. Department of Agriculture, Agricultural Research Service, South Central \\ Agricultural Research Laboratory, P.O. Box 159, Lane, OK 74555
}

Additional index words. Capsicum annuum, culture, harvest timing

\begin{abstract}
Planting date, fertilizer rate, and timing of harvest can affect yield of Jalapeño and banana peppers (Capsicum annuum L.). Seedlings of the Jalapeño 'Mitla' and Long yellow wax 'Sweet Banana \#504' were transplanted in Apr. and July 1995 into beds fertilized with either a recommended or a higher rate. Fruit were harvested either three times or once, the latter corresponding to the last of several harvests. Significantly higher yields were produced from the July planting of both cultivars and with once-over harvesting. The recommended rate of fertilizer increased yield of 'Sweet Banana\#504' and decreased that of 'Mitla' compared to the higher rate.
\end{abstract}

Pungent and nonpungent peppers (Capsicum annuum L.) (Andrews, 1995; Bosland, 1992; Smith et al., 1987) are becoming increasingly popular in the United States.

Expanded production into new areas may be necessary to meet demands, and southeastern Oklahoma could become an area for pepper production. In new areas, it is necessary to determine what factors could limit production. Fertilizer rate, especially $\mathrm{N}$, influences yield (Locascio et al., 1981). Air temperature, which is associated with planting date, is known to affect pepper flower abscission (Rylski, 1973). If a crop can be harvested with a single pass, production costs might be reduced, especially if yield is similar to that of multiple harvests. This research was designed to determine how fertilizer rate, planting date, and timing of harvest affected marketable yield of two pepper types in southeastern Oklahoma.

\section{Materials and Methods}

The experiment was conducted on a Bernow fine-loamy, siliceous, thermic Glossic Paleudalf soil at Lane, Okla. The planting area was $0.12 \mathrm{ha}(20 \times 60 \mathrm{~m})$. Fertilizer was applied preplant so that half of the area received the recommended rate $\left(\mathrm{Kg} \cdot \mathrm{ha}^{-1}\right), 112 \mathrm{~N}-112 \mathrm{P}-$ 325K (McCraw and Motes, 1987), and the other received an additional $160 \mathrm{~N}-160 \mathrm{P}-$ $406 \mathrm{~K}$. The source of $\mathrm{N}$ was ammonium nitrate; $\mathrm{P}$ was $\mathrm{P}_{2} \mathrm{O}_{5}$; and $\mathrm{K}$ was $\mathrm{K}_{2} \mathrm{O}$. Raised beds formed from bare soil were oriented northsouth on $0.9-\mathrm{m}$ centers. Plots, established ran-

Received for publication 12 Apr. 1996. Accepted for publication 28 July 1996. Mention of a trademark, vendor, or proprietary product does not constitute a guarantee or warranty of the product by the U.S. Dept. of Agriculture and does not imply its approval to the exclusion of other products that may also be suitable. The cost of publishing this paper was defrayed in part by the payment of page charges. Under postal regulations, this paper therefore must be hereby marked advertisement solely to indicate this fact. domly within $60-\mathrm{m}$-long rows, were $9.2 \mathrm{~m}$ long. Six-week-old seedlings of 'Mitla' (Petoseed, Saticoy, Calif.), hybrid Jalapeño of the area within a fertilizer rate. Same age seedlings of 'Sweet Banana \#504' (Twilley Seed Co., Trevose, Pa.), long yellow wax group (nonpungent), were transplanted into the other half.

The spring planting was on 14 Apr. 1995. All plants were on an in-row spacing of 0.46 $\mathrm{m}$, and there were 20 plants of each cultivar in each plot. Half the plants in each plot were hand-pulled during three harvests over 14 days, with the first harvest on 7 June 1995. The other 10 plants in each plot were harvested once, at the same time as the third harvest of the plots that had multiple harvests. After the last hargroup (pungent), were transplanted into half vest of the spring planting, the remaining plants were removed from beds with a rotary mower. The same land area was prepared and fertilizer reapplied at the same rates. Sameaged seedlings of the same cultivars used in the spring were transplanted on 12 July 1995 , with the first harvest on 5 Sept. 1995.

For both plantings, number and yield of marketable fruit were determined. Marketable fruit for 'Sweet Banana \#504' were yellow and a minimum of $4 \mathrm{~cm}$ wide $\times 15 \mathrm{~cm}$ long, and for 'Mitla' a minimum of $3.8 \mathrm{~cm}$ wide $\times 5 \mathrm{~cm}$ long. Marketable jalapeño peppers are desired to be dark green (Daniello, 1995). For purposes of this experiment, 'Mitla' fruit were considered marketable if they were dark green. Plants received a minimum of $30 \mathrm{~mm}$ of water/ week in the form of precipitation or overhead irrigation.

At both planting dates, the design was a split-plot with eight replications, with fertilizer rate being the main plot and harvest timing for each cultivar being the subplot. The data were analyzed with the general linear models procedures in SAS (ver. 6.1, SAS, Cary, N.C.).

\section{Results and Discussion}

Yields for both types of peppers for the two plantings differed (Table 1). In the spring planting more 'Mitla' fruit were produced for weekly harvests than those harvested once, but yield was not affected. However, fertilizer rate and harvest frequency generally did not affect yield of either cultivar. For the midsummer planting, fertilizer rate and harvest frequency affected marketable number of fruit and yield. There was no significant interaction $(P \leq 0.05)$ between fertilizer rate and harvest frequency for either planting.

In the midsummer planting, the low (recommended) fertilizer rate increased yields for 'Sweet Banana \#504' relative to the high rate,
Table 1. Effects, in each production season, of fertilizer rate, harvest frequency, and their interaction, on marketable number and yield of fruit of 'Sweet Banana \#504' and 'Mitla' peppers.

\begin{tabular}{|c|c|c|c|c|}
\hline \multirow[b]{4}{*}{ Variable } & \multicolumn{4}{|c|}{ Pepper type } \\
\hline & \multicolumn{2}{|c|}{ Sweet Banana \#504 } & \multicolumn{2}{|c|}{ Mitla } \\
\hline & \multicolumn{4}{|c|}{ Marketable fruit } \\
\hline & $\begin{array}{l}\text { No./ha } \\
\text { (1000s) }\end{array}$ & 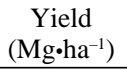 & $\begin{array}{l}\text { No./ha } \\
(1000 \mathrm{~s})\end{array}$ & $\begin{array}{c}\text { Yield } \\
\left({\left.\mathrm{Mg} \cdot \mathrm{ha}^{-1}\right)}\right.\end{array}$ \\
\hline \multicolumn{5}{|c|}{ Spring planting ${ }^{z}$} \\
\hline \multicolumn{5}{|c|}{ Fertilizer rate $(\mathrm{F})$} \\
\hline Low & 111 & 3.4 & 158 & 2.7 \\
\hline \multirow[t]{2}{*}{ High } & 143 & 3.8 & 147 & 2.5 \\
\hline & NS & NS & NS & NS \\
\hline \multicolumn{5}{|c|}{ Harvest frequency $(\mathrm{H})$} \\
\hline Once & 117 & 3.4 & 127 & 2.3 \\
\hline \multirow[t]{2}{*}{ Weekly } & 132 & 3.4 & 165 & 2.7 \\
\hline & NS & NS & * & NS \\
\hline \multicolumn{5}{|c|}{ Midsummer planting } \\
\hline \multicolumn{5}{|c|}{ Fertilizer rate } \\
\hline Low & 449 & 14.1 & 403 & 6.4 \\
\hline \multirow[t]{2}{*}{ High } & 338 & 9.0 & 732 & 11.9 \\
\hline & $* *$ & $* *$ & $* *$ & $* *$ \\
\hline \multicolumn{5}{|c|}{ Harvest frequency } \\
\hline Once & 585 & 19.1 & 754 & 13.9 \\
\hline \multirow[t]{2}{*}{ Weekly } & 298 & 7.8 & 474 & 6.8 \\
\hline & $* *$ & $* *$ & $* *$ & $* *$ \\
\hline
\end{tabular}

${ }^{\mathrm{z}}$ The interaction $\mathrm{F} \times \mathrm{H}$ was nonsignificant $(P \leq 0.05)$ for either planting.

Ns, *,** Nonsignificant or significant at $P \leq 0.05$ or 0.01 , respectively, for each planting. 
but the additional fertilizer increased yields for 'Mitla'. The reason for this difference is not clear; however, based on visual observation, foliage appeared to be produced at the expense of fruit for 'Sweet Banana \#504'. A single harvest for the midsummer planting increased yield for both cultivars over that from plants with several harvests.

Fruit was harvested early in the day, which may have caused more damage to the plants, because they are more brittle in the morning than in the afternoon (B. Villallon, personal communication)

For jalapeño and long yellow wax peppers, mechanical harvesting is a possibility (Marshall et al., 1990). If timed to produce as many marketable fruit as possible, both pepper types can be harvested with a single pass through the field. Where conditions are similar to this location, growers should give priority to midsummer, as opposed to spring, planted peppers. However, attention should be given to fertilizer level and how it affects yield of specific pepper types. A single harvest may reduce production costs as compared to multiple harvests.

\section{Literature Cited}

Andrews, J. 1995. Peppers. The domesticated Capsicums. Univ. Texas Press, Austin.

Bosland, P.W. 1992. Chiles: A diverse crop. HortTechnology 2:6-10
Dainello, F.J. 1995. Commercial vegetable production guide 1995. Texas Agr. Expt. Sta., College Station.

Locascio, S.J., J.G.A. Fiskell, and F.G. Martin. 1981. Response of bell pepper to nitrogen sources. J. Amer. Soc. Hort. Sci. 106:628-632.

McCraw, D., and J.E. Motes. 1987. Fertilizing commercial vegetables. Okla. State Univ. Ext. Facts, No. 6000.

Marshall, D.E., M.G. Pickett, and T.A. Esch. 1990. Using air to convey mechanically harvested peppers. Trans. ASAE. 33:47-50.

Rylski, I. 1973. Effect of night temperature on shape and size of sweet pepper (Capsicum anпиит L.). J. Amer. Soc. Hort. Sci. 98:149-152.

Smith, P.G., B. Villalon, and P.L. Villa. 1987. Horticultural classification of peppers grown in the United States. HortScience 22:11-13. 